\title{
Comparative study on Labneh cheese made from milk fat and avocado paste
}

\author{
H. M. Ali * \\ Dairy Department, Faculty of Agriculture, Al-Azhar University, Cairo, Egypt \\ *Correspondence: Heshamsary.5@azhar.edu.eg (H. Ali)
}

\begin{abstract}
The present study was carried out to prepare a healthy Labneh cheese from fresh whole buffalo's milk and avocado paste en route to innovate a functional food. To achieve the purpose of this research, a pasteurized buffalo's milk (at $74^{\circ} \mathrm{C}$ for $15 \mathrm{sec}$ ) was cooled immediately to $40^{\circ} \mathrm{C}$ and divided into four equal quantities. The first quantity was manufactured as a control. The second, third, and fourth quantities were mixed with avocado paste and $0.1 \%$ disodium citrate at percentages of 5,10 and $15 \%$, respectively then stirred well to obtain uniform mixtures. Then a concentration of $4 \%$ fresh prepared bacterial yoghurt starter culture was added for all milk portions and incubated at $40{ }^{\circ} \mathrm{C}$. The incubation was terminated at $\mathrm{pH}$ 4.8. All treatments were put into cloth bags and hung up in a refrigerator to allow whey to drain for $12 \mathrm{~h}$, then $1 \%$ salt was added and filled into suitable containers. The obtained results showed that, the Labneh fortification with avocado paste up to $5 \%$ led to improve the body and the texture and did not clearly affect the appearance and the flavor. While the exceeding avocado paste addition to $15 \%$ led to a decrease in the degrees of texture, body and appearance. Also it was determined the total cost of one $\mathrm{kg}$ Labneh cheese containing $5 \%$ avocado paste increased only by $8.9 \%$ versus the control. Finally, the forgoing results led satisfactory to conclude that, it could successfully made a Labneh cheese that meets the intended health purposes based on the fortification with $5 \%$ avocado paste of many impressive health benefits en route to innovate a functional food.
\end{abstract}

Keywords: Physiochemical properties, Microbiological situation, Sensory quality, Economic evaluation.

\section{INTRODUCTION}

The relationship between diet and health became the focus of consumer attention (Behall et. al., 2006). From a nutritional view, the avocado paste contains mostly valuable unsaturated fatty acids, protein, carbohydrates, quantities of vitamins C, B, E, and A. Long time ago, the avocado fruits had been recognized with relatively higher nutrition value as compared to other fruits (Bernice et. al., 1959; Pierce 1959; Oche et. al., 1961).

At the parallel time, Labneh (yogurt cheese) is easily made at home by draining the whey from yogurt. Concentrated yogurt (Labneh) is defined by the Lebanese Standards as a semisolid food derived from yoghurt by draining away part of its whey and some water-soluble compounds. The total solids (TS) are typically $23-25 \%$ and the product has a cream/white color, a soft and smooth body, good spread ability and a flavor that is clean and slightly acidic (Lebanese Standards, 1965; Hamad and Al-Sheikh 1989).

Therefore, the objective of this study is to produce a fresh good quality and healthy Labneh cheese made from buffalo's milk and fortified with avocado paste en route to innovate a functional food.

\section{MATERIALS AND METHODS}

\section{Materials}

A fresh whole buffalo's milk (4\% protein, $0.7 \%$ ash, $6 \%$ fat and $4.6 \%$ lactose) was supplied from the Farm of Faculty of Agriculture, AlAzhar University, Cairo, Egypt. Imported avocado (Persea americana) and disodium citrate were purchased from local markets. Fine edible commercial grade salt produced by EL-Fanar Co. was used. Bacterial yoghurt starter culture (YSC) (containing Streptococcus thermophiles and Lactobacillus delbruckii subsp. Bulgaricus) was purchased from Danisco France SAS CO., rude de Clemencieres Bp 32 3836, Sassmenage, France.

\section{Experimental procedures \\ Preparation of avocado paste}

The outer layer and the layer which surrounded the seeds were separated carefully from the ripe avocado after that the pulp of avocado kept in polyethylene in the deep freezer at $-20^{\circ} \mathrm{C}$ until use.

\section{Labneh cheese avocado manufacture.}

Pasteurized buffalo's milk (at $74^{\circ} \mathrm{C}$ for 15 sec) was cooled immediately to $40^{\circ} \mathrm{C}$ and divided into four equal parts. The first quantity was conventionally manufactured as a control according to Hamad and Al-Sheikh (1989). The 
second, third and fourth quantities were mixed with avocado paste and $0.1 \%$ disodium citrate at the level of 5,10 and $15 \%$, respectively then stirred well to obtain uniform mixtures. Then $4 \%$ of fresh prepared YSC was added for all milk portions and incubated at $40^{\circ} \mathrm{C}$. Incubation was terminated at $\mathrm{pH}$ 4.8. All treatments were put into cloth bags and hung up in a refrigerator to allow whey to drain for $12 \mathrm{~h}$, then $1 \%$ salt was added and filled into suitable containers.

\section{Analytical methods}

Moisture, total solids, protein, salt and ash contents of avocado cheese were determined according to AOAC (2012). The protein content was obtained by multiplying the percentage of total nitrogen by 6.38 for milk ingredients and 6.25 for plant ingredients. The $\mathrm{pH}$ value was measured using a Swiss Gallenkamp stick $\mathrm{pH}$ meter with glass electrode. Fat content was determined according to Ling (1963). The oil content of avocado paste (using the Soxhlet method) and fiber content were determined according to AOAC (2012). Total bacterial count, coliform as well as molds and yeasts counts were enumerated according to APHA (1992). Organoleptic properties of different treatments were assessed by members of the department according to the following score card (30 for appearance 30 for flavor, 20 for body and 20for texture) suggested by Aly et al. (2004).

\section{RESULTS AND DISSCUSSION}

\section{Physio-chemical properties of avocado paste}

Results displayed in Table (1) show that the highest percentage of the avocado paste components were the moisture followed by the fat, fibers, protein, total carbohydrates and ash respectively. It was also observed that the $\mathrm{pH}$ value was 6.8. These results are in agreement with those reported by EL-Barkouki et. al. (1970) and Fahmy (1970).

Physico-chemical properties of Labneh cheese as a function of the fortification level with avocado paste

According to results shown in Table (2) it could be pointed out that the addition of avocado paste to Labneh cheese milk increase the total solids, fat and salt contents of the resultant cheese compared to the control. While the protein and ash percentage decreased with increasing the avocado paste level. This may be due to the relatively high fat content and the low protein content of avocado paste as given in Table (1). These results are in agreement with those reported by Bora et. al. (2001), Arukwe et. al. (2012), Adegoke et. al. (2012) and Dabas et. al. (2013).

Microbiological situation of Labneh cheese as a function of the fortification level with avocado paste

It was obvious from the results present in Table (3) that the total counts of bacteria of Labneh cheese treatments containing avocado paste were lower than that in control. The decrease in total counts of bacteria of Labneh cheese treatments containing avocado paste versus the control may be attributed to the high viscosity and the lack of available water activity. Moreover, it could be observed that the coliform bacteria as well as molds and yeasts were absent in all Labneh cheese treatments. That could be due, indeed, to the sanitation condition adapted along the manufacturing steps.

Organoleptic quality of Labneh cheese as a function of the fortification level with avocado paste

Results in the arbitration diagram (Figure, 1) showed that, although, neither the score of appearance nor that of flavor was affected, the addition of avocado paste up to $5 \%$ led to improve both the body and the texture scores. While the addition of avocado paste up to $15 \%$ resulted in a decrease in the degrees of texture, body and appearance of resultant Labneh cheese.

Economic recovery of Labneh cheese as a function of the fortification level with avocado paste

The cost of the different Labneh cheese could be declared from the data of Table (4), which shows the price list for the raw materials used in Labneh cheese manufacture. The total cost for $1 \mathrm{~kg}$ of different Labneh cheese treatments were 24.76, 26.83, 29.2 and 31.44 (LE) for control, T1, T2 and T3 respectively. From these values it could be observed that the total cost of $1 \mathrm{~kg}$ Labneh cheese containing avocado paste increased by 8.9 - $26.9 \%$ compared with the control. This increase could be attributed to the higher price of avocado paste when compared to the price of traditional solids.

\section{CONCLUSION}

Finally, the forgoing results led satisfactory to conclude that, it could successfully made a Labneh cheese that meets the intended health purposes based on the fortification with $5 \%$ avocado paste of many impressive health benefits en route to innovate a functional food. 


\section{REFERENCES}

APHA, American Public Health Association, 1992. Compendium of methods for the microbiological examination of foods. $3^{\text {th }}$ Ed., Washington DC, USA.

Adegoke, G.O., Akinbile, J.T., Olapade, A.A., Ashaye, O.A., 2012. The effect of processing methods on the nutritional profile of avocado (Persea americana Mill) seeds. Achiev. Sustain. Dev. Afr., 11 (2), 186-194.

Aly, S.A., Galal, E.A., Elewa, N.A., 2004. Carrot Yoghurt: Sensory, Chemical, Microbiological Properties and Consumer Acceptance Food Hygiene Department, Faculty of Veterinary Medicine, Cairo University, Egypt.

AOAC, Association of Official Analytical Chemists, 2007. Official Methods of Analysis. $18^{\text {th }}$ Ed., Benjamin Franklin Station Washington, D.C., USA.

Arukwe, U, Amadi, B.A., Duru, M.K.C., 2012. Chemical composition of Persea americana leaf, fruit and seed. Int. Res. Reviews Appl. Sci., 11 (2), 346-349.

Behall, K.M., Scholfield, J.D., Hallfrisch, J.G., 2006. Barley glucan reduce plasma glucose and insulin responses compared with resistant starch in men. Nutr. Res., 12, 644-650.

Bernice, K.W., Annabel, L.M., Hartha, L.O., 1959. A table of food values. Food the year Book Agric. U.S.D.A., Washington, D. C., 237.
Bora, P.S., Narain N., Rocha, R.V.M., Paulo, Q.M., 2001. Characterization of the oils from the pulp and seeds of avocado (cultivar: Fuerte) fruits. Grasas Aceites, 52 (3-4), 171-174.

Dabas, D., Shegog, R.M., Ziegler, G.R., Lambert, J.D., 2013. Avocado (Persea americana) seed as a source of bioactive phytochemicals. Curr. Pharm. Des., 19 (34), 6133-6140.

El-Barkouki, M., Higazy, M.K., Fahmy, M.A., 1970. Developmental changes of Fuerte avocado fruit through maturation. Res. Bull. Fac. Agric. EinShams Univ., 615, 18.

Fahmy, M.A., 1970. Studies on some avocado varieties in UAR. M.Sc. Thesis, Fac. Agric., AlAzhar Univ., Cairo.

Hamad, A.M., Al-Sheikh, S., 1989. Effect of milk solids concentration and draining temperature on the yield and quality of Labneh (concentrated yoghurt). Cult. Dairy Prod. J., 24 (1) $25-28$.

Lebanese Standards, 1965. LS-24. Lebanese Standards Institution, PO Box 2806, Beirut, Lebanon.

Ling, L.R., 1963. A Text Book of Dairy Chemistry Vol. 11. Chapman and Ltd, London.

Oche, J.J., Soule, M.J., Digkman, M.J., Wehblung, C., 1961. Tropical and Subtropical Agriculture. Vol. 1, The MacMillan Co., New York, pp. 617.

Pierce, H.F., 1959. The Nutritional Value of The Avocado. California Avocado Society. Year Book, California, pp. 1120.

Table 1. Physio-chemical properties of avocado paste

\begin{tabular}{cc}
\hline Property & Value \\
\hline Moisture & $73.0 \%$ \\
Oil & $20.0 \%$ \\
Protein & $2.5 \%$ \\
Fibers & $3.0 \%$ \\
Carbohydrates & $1.2 \%$ \\
Ash & $0.3 \%$ \\
\hline pH value & 6.8 \\
\hline
\end{tabular}

*Calculate by the differences

Table 2. Physico-chemical properties of Labneh cheese fortified with avocado paste

\begin{tabular}{ccccc}
\hline \multirow{2}{*}{ Property } & \multicolumn{4}{c}{ Fortification level with avocado paste } \\
\cline { 2 - 4 } & Nil (Control) & $\mathbf{5 \%}$ & $\mathbf{1 0 \%}$ & $\mathbf{1 5 \%}$ \\
\hline Total solids \% & 27.42 & 28.18 & 29.28 & 30.32 \\
Fat \% & 12.47 & 13.80 & 15.17 & 16.48 \\
Protein \% & 7.29 & 7.10 & 6.94 & 6.75 \\
Ash \% & 0.76 & 0.65 & 0.62 & 0.58 \\
salt \% & 2.70 & 2.82 & 3.07 & 3.35 \\
pH value & 4.20 & 4.17 & 4.12 & 4.11 \\
\hline
\end{tabular}


Table 3. Microbiological situation of Labneh cheese fortified with avocado paste

\begin{tabular}{ccccc}
\hline \multirow{2}{*}{ Count } & \multicolumn{4}{c}{ Fortification level with avocado paste } \\
\cline { 2 - 5 } & Nil (Control) & $\mathbf{5 \%}$ & $\mathbf{1 0 \%}$ & $\mathbf{1 5 \%}$ \\
\hline Total bacterial & $6.9 \times 10^{7}$ & $6.0 \times 10^{7}$ & $4.5 \times 10^{7}$ & $3.6 \times 10^{7}$ \\
Coliform & $\mathrm{NF}$ & $\mathrm{NF}$ & $\mathrm{NF}$ & $\mathrm{NF}$ \\
Yeasts\& Molds & $\mathrm{NF}$ & $\mathrm{NF}$ & $\mathrm{NF}$ & $\mathrm{NF}$ \\
\hline
\end{tabular}

NF: not found

Table 4. Economical study of different Labneh cheese treatments.

\begin{tabular}{|c|c|c|c|c|c|c|c|c|c|}
\hline \multirow{3}{*}{ Basic material } & \multirow[b]{3}{*}{$\begin{array}{l}\text { Price } \\
\text { (L.E/ } \\
\mathrm{Kg} \text { ) }\end{array}$} & \multicolumn{8}{|c|}{ Fortification level with avocado paste } \\
\hline & & \multicolumn{2}{|c|}{ Nil (Control) } & \multicolumn{2}{|c|}{$5 \%$} & \multicolumn{2}{|c|}{$10 \%$} & \multicolumn{2}{|c|}{$15 \%$} \\
\hline & & $\begin{array}{l}\text { Quantit } \\
\text { y }(\mathrm{Kg})\end{array}$ & $\begin{array}{l}\text { Valu } \\
\text { e L.E }\end{array}$ & $\begin{array}{l}\text { Quantit } \\
\text { y Kg. }\end{array}$ & $\begin{array}{l}\text { Value } \\
\text { L.E }\end{array}$ & $\begin{array}{l}\text { Quantit } \\
\text { y Kg. }\end{array}$ & $\begin{array}{l}\text { Valu } \\
\text { e L.E }\end{array}$ & $\begin{array}{l}\text { Quantit } \\
\text { y Kg. }\end{array}$ & $\begin{array}{l}\text { Value } \\
\text { L.E }\end{array}$ \\
\hline $\begin{array}{l}\text { Whole } \\
\text { buffalo's } \\
\text { Milk }\end{array}$ & 11 & 10 & 110 & 9.5 & 104.5 & 9 & 99 & 8.5 & 93.5 \\
\hline $\begin{array}{l}\text { Bacterial } \\
\text { culture }\end{array}$ & 25 & 0.4 & 10 & 0.4 & 10 & 0.4 & 10 & 0.4 & 10 \\
\hline Avocado paste & 35 & - & - & 0.5 & 17.5 & 1 & 35 & 1.5 & 52.5 \\
\hline Salt & 3.3 & 0.1 & 0.33 & 0.1 & 0.33 & 0.1 & 0.33 & 0.1 & 0.33 \\
\hline $\begin{array}{l}\text { Disodium } \\
\text { citrate }\end{array}$ & 25 & 0.01 & 0.25 & 0.01 & 0.25 & 0.01 & 0.25 & 0.01 & 0.25 \\
\hline Making cost & 1 & 4.91 & 4.91 & 4.94 & 4.94 & 4.95 & 4.95 & 4.98 & 4.98 \\
\hline Cheese yield & & 4.91 & & 4.94 & & 4.95 & & 4.98 & \\
\hline Total cost & & & 25.56 & & 27.84 & & 30.21 & & 32.44 \\
\hline
\end{tabular}

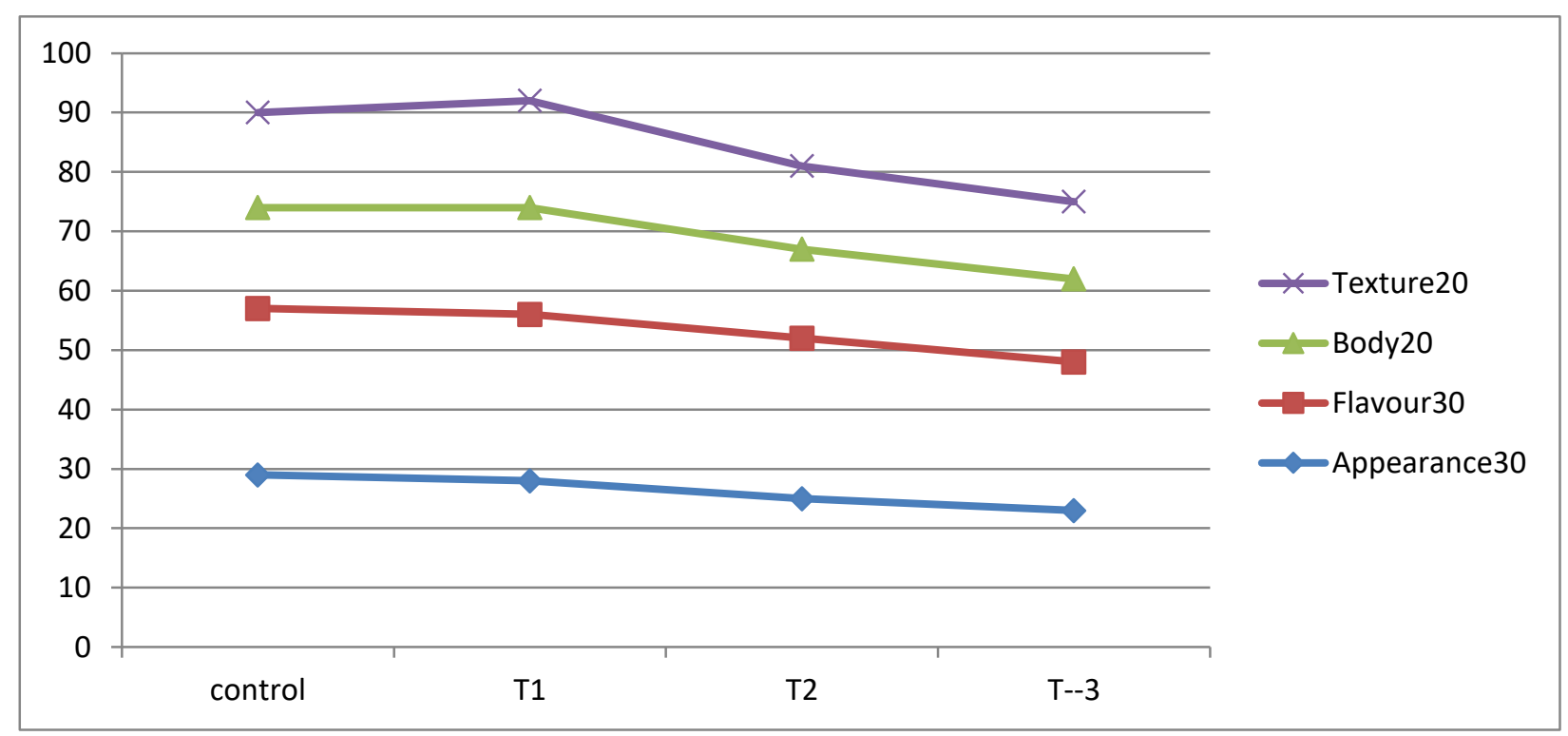

Figure 1. organoleptic properties of Labneh cheese fortified with avocado paste

Note: $\mathrm{T}_{1}$ : Labneh with $5 \%$ avocado pasta. $\mathrm{T}_{2}$ : Labneh with $10 \%$ avocado pasta. $\mathrm{T}_{3}$ : Labneh with $15 \%$ avocado pasta 


\title{
دراسة مقارنة علي جبن اللبنة المصنعة من دهن اللبن ويجينة الافوكادو
}

\author{
هشام محمد علي" \\ قسم الألبان، كلية الزراعة بالقاهرة، جامعة الازهر، القاهرة، مصر
}

البريد الإليكتروني للباحث الرئيسي: Heshamsary.5@azhar.edu.eg

\section{الملخص العربي}

أجريت الدراسة الحالية لتحضير لبنة صحية من اللبن الجاموسى الكلمل الطازج والمدع بلب الأفوكادو من أجل ابتكار غذاء وظيفي جديد. ولتحقيق هذا

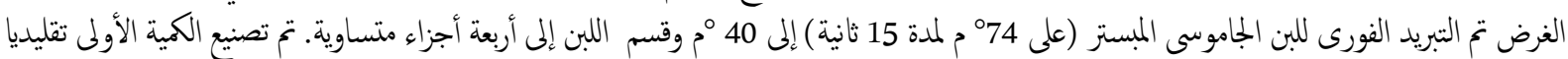

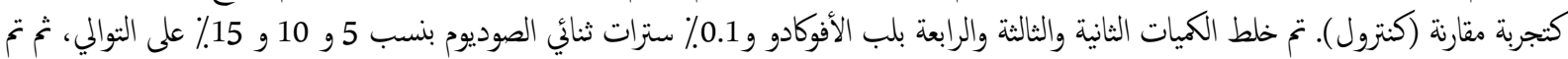

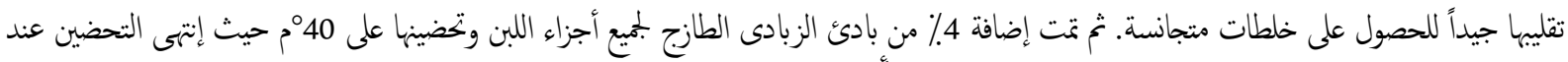

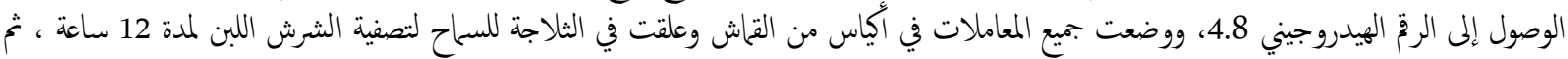

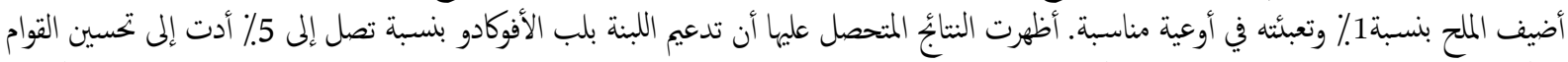

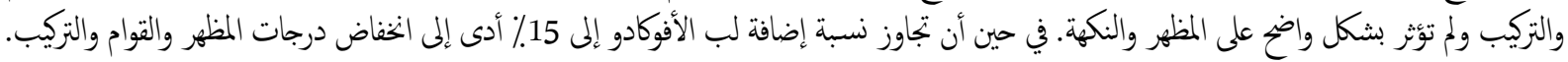

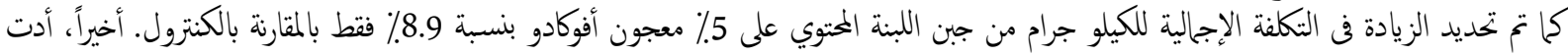

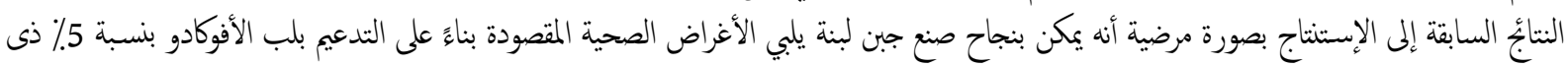

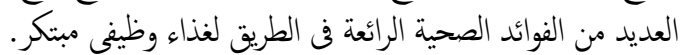
الكلمات الاسترشادية: الخصائص الفيزيويميائية، الوضع الميكروبيولوبئية الفيكي، الجودة الحسية، التقييم الاقتصادي. 